\title{
ガイド型金属粉末射出成型体の焼結時における不均一収縮
}

\author{
瀧澤 将的, 渡辺 龍三的, 川崎亮的

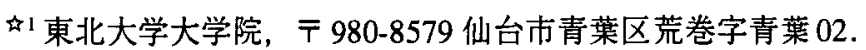 \\ 4 2 東北大学大学院工学研究科材料加工プロセス学専攻, $\bar{\top} 980-8579$ 仙台市青葉区荒巻字青葉 02 .
}

\section{Non-uniform Shrinkage of Guide-type MIM Compact During Sintering}

\author{
Susumu Takizawa ${ }^{41}$, Ryuzo Watanabe ${ }^{\text {क2 } 2}$ and Akira Kawasaki 2 \\ 4 'Graduate school, Tohoku University, 02 Aoba Aramaki Aoba-ku, Sendai 980-8579. \\ ${ }^{2} 2$ School of Engineering, Tohoku University, 02 Aoba Aramaki Aoba-ku, Sendai 980-8579.
}

Received January 15, 2091

\section{SYNOPSIS}

In-situ measurement of non-uniform sintering shrinkage of guide-type (ring-on-plate) MIM compacts was made by digital image correlation method. The shrinkage distribution and the distortion in the compacts were determined with a dimensional accuracy of $3 \mu \mathrm{m}$. A periodical shrinkage distribution in the ring portion was observed in the compact during sintering, due to density distribution generated presumably by an uneven injection flow from gates located at the both ends of the base plate. An upward warpage of the base plate and a collapse of the ring portion were also observed. The inhomogeneous radial shrinkage, the base-plate-warpage and the ring-collapse were interpreted in terms of the ring-portion density distribution and the effect of gravity. The periodical variation in the radius distribution during sintering was attributed to the green density distribution. A simple geometrical consideration showed that the distortion due to gravity was estimated to be approximately $2 \%$ at the most.

\section{KEY WORDS}

in-situ measurement, digital image correlation method, sintering shrinkage, metal injection molding, nonuniform shrinkage

\section{1 序論}

金属射出成型体は易焼結性で複雑形状のため焼結条件の変 動に敏感であり，不均一変形が起こりやすく，いかにして所 定の形状寸法に制御するかが大きな問題となっている ${ }^{1.2)}$. 著 者らは年8), 部材の焼結中における不均一変形を非接触かつ実 時間的に測定できるシステムを開発し，各種射出成型体の焼 結過程に㧧ける寸法変化を測定した，その結果, 射出成型体 の不均一焼結変形は, (1)部位による微小な温度差, (2)重力, (3) 試料と支持台間の摩擦拘束, および(4)試料内部の密度差に起 因することが明らかになった，金属射出成型体の場合，形状 が複雑なために均一な加熱が難しく，また薄い部分や細い部 分があるため重力などの影響を受けやすい．前報8ではコの 字型の射出成型体について測定を行い，初期相対密度分布の 変動による不均一変形を報告した。本研究では, 環状部と直 線的基底部を有し，かつ，ゲート位置の関係で内部密度にむ らがあることが予想されるガイド型射出成型体について，非 接触・実時間的な測定を行い, 主として密度分布及び重力に
起因する不均一变形のメカニズムを検討した。

\section{2 実験}

デジタル像相互相関法は物体の表面各部に固有な光の散乱 に上る輝度分布を利用して, 変形の前後における物体表面の 同一点を特定し，その変位を算出する方法である。まず測定 時の比較画像と变位前の基準画像の画像データから測定点を 中心として Fig.1のような小領域 (参照領域)における各画素 の輝度值を取り出す，次にこの両者の輝度值群の間で相関值 を計算する。これを比較画像に設定したある範囲(探索領域) 内の全ての点について繰り返し, その中で最も高い相関を得 たものを同一点位置として決定する. 相関値 3 (-8)は統計学にお ける 2 变数の相関係数と同じであり, 参照領域内の各画素の 輝度を標準偏差で規格化したものであり，最も相関が高い場 合に最大値の1を得る．精度の良い測定のためには基準画像 と比較画像との間に強い相関が必要だが，焼結の進行ととも に試料の表面状態は変化するため, 最初の画像と相関を取り 
つづけることは不可能となる。 そこで, 基準画像と比較画像 との相関が取れないと判断された場合, 確実に相関が取れる 前回測定画像を新たな基準画像に切り替える。しかし，この 時に線形補間による測定誤差が残るため, 切り替えの回数は 最小限にする必要がある。そこで前回画像と基準画像の両者 についての，比較画像に対する相関計算による結果の座標が 測定精度範囲から外れる場合のみ切り替えを行うこととした。 また，通常は複数の測定点を同時に設定するが，切り替えの 判断および参照する基準画像のデータを測定点ごとに独立さ せることで, 各測定点は設定される点の数に左右されず固有 の測定精度を有する。

本実験に用いたin-situ焼結収縮計測システム ${ }^{3-8)}$ は，空付き の炬内をキセノンランプで照明し，試料表面で散乱される光 を炉内で放射される長波長光を除去するためのフィルターを 通してCCDカメラで採光し, ワークステーションに入力して データ処理するものである. 画像処理原理はデジタル像相互 相間法に基づいており，特に高温での焼結変形を追跡できる ように改良を加えている ${ }^{3)}$. 入力されるデジタル画像は $432 \times$

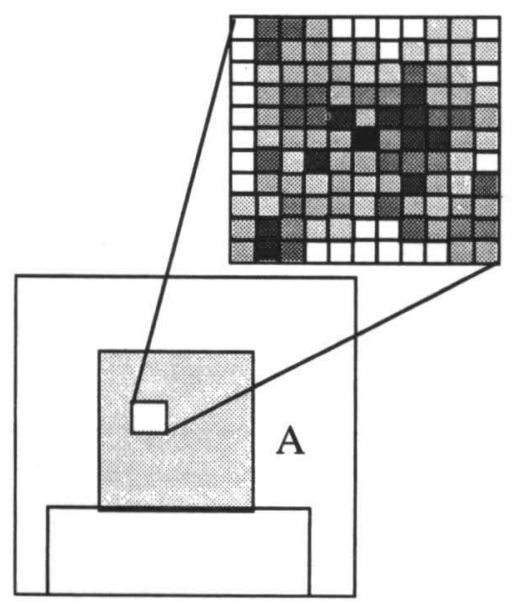

Fig.1 Principles of identifying initial point by digital image correlation. A: sample, B: brightness distribution.

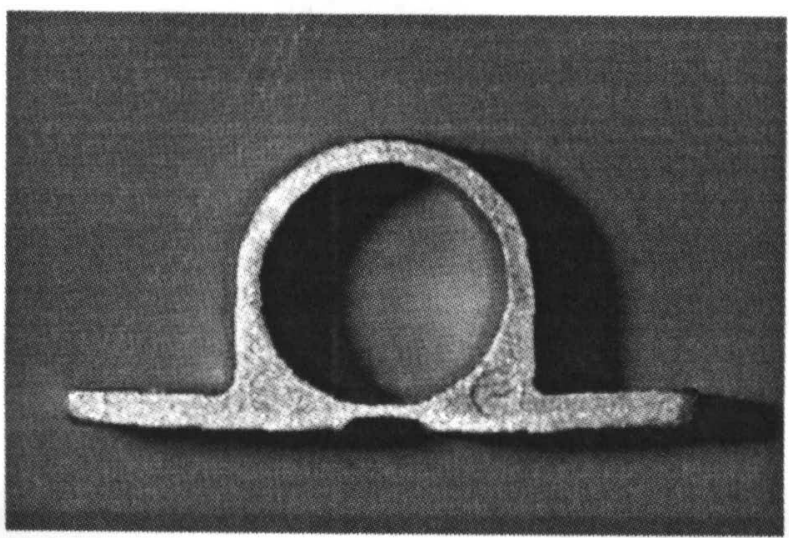

Fig.2 Photograph of sintered MIM compact exhibiting inhomogeneous deformation and warpage, (sintering temperature; $1150^{\circ} \mathrm{C}$ ).
512 画素より成り, サイズが $15 \mathrm{~mm}$ 程度の試料の測定では約 $30 \mu \mathrm{m} /$ pixel の解像度が得られる。 また特定できる変位の最小 値は画素間の線形補間を併用することにより 0.1 画素である.

供試料はSUS316の MIM成型体を予め脱脂したもので，原 料粉平均粒径は $7.5 \mu \mathrm{m}$ である. Fig. 2 に供試成形体 (焼結後の もの)を示す. 本試料は穴のあいた基板の上に環状部が載った 形状である。測定は, Fig.3に示した成型体模式図の，環状部 について右側の水平方向位置を $0^{\circ}$ として左回りに 12 点と基底 板部の側面に直線で 6 点の 2 種の部分について行った。

試料の焼結は, $293 \mathrm{~K} \sim 1123 \mathrm{~K}$ までは $10 \mathrm{~K} / \mathrm{min} て ゙, 1123 \mathrm{~K} \sim$ $1423 \mathrm{~K}$ までは $5 \mathrm{~K} / \mathrm{min}$ で昇温し，その後 2 時間保持した，測定 は2 5分毎に行った. 試料内の密度分布は光学顕微鏡下での 画像解析により求めた.

\section{3 結 果}

Fig.4に環状部に沿った焼結前の成型体における気孔率(100相対密度)の角度 $\theta$ に対する変化を示す. 気孔率分布は周期的 な変化を示すが左右 $\left(0 \sim 90^{\circ}\right.$ と $\left.90 \sim 180^{\circ}\right)$ で非対称な変化が見 られ，これは充填時における左右のゲートからの粉末の流れ の差すなわち，充填密度差があったことを示している．また 角度 $30^{\circ}$ と $210^{\circ}$ に気孔率の最大值があり，一方で $120^{\circ}$ と $300^{\circ}$

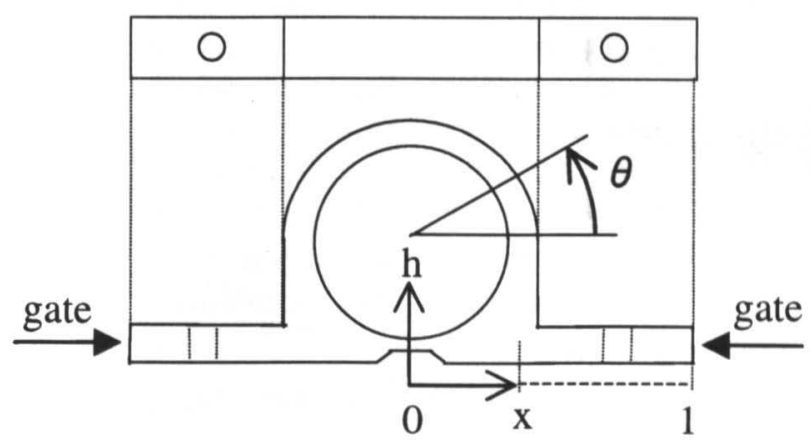

Fig.3 Illustration of the MIM compact (ring-on-plate) with positions of injection gates.

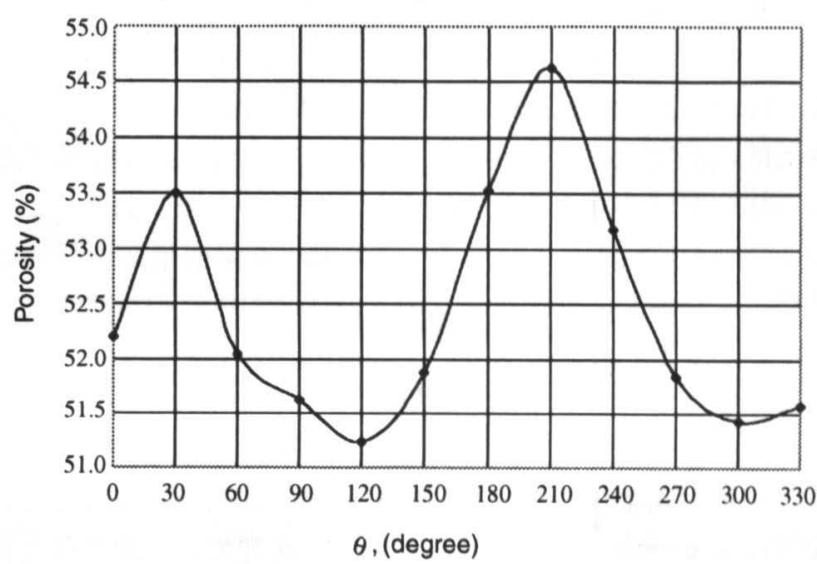

Fig.4 Initial porosity distribution of MIM compacts along the circumference of the ring portion. 
に最小値がある.最大値と最小值の差は約 $3 \%$ り, 不均一変 形の発生が十分に予想される. Fig. 5 に同じく $850^{\circ} \mathrm{C} \sim 1150^{\circ} \mathrm{C}$ に昇温したときの環状部に沿った半径変化を示す。ここで角 度 $\theta$ に対する半径は初期值を 1 として標準化してある. $850^{\circ} \mathrm{C}$ および $950^{\circ} \mathrm{C} の$ 昇温時は僅かに膨張し，1050 ${ }^{\circ} \mathrm{C}$ おび $1150^{\circ} \mathrm{C}$ の昇温時は9〜10\%の程度の収縮が見られる。また, 気孔率の 場合と同様に，環状部に沿って半径に周期的な変化が見られ る.一般に気孔率が大きいほど収縮率が大きいはずであるが 観測值は全く逆の傾向を示している。この点について，環状 部における円周方向の収縮と半径方向の収縮の関係として次 項で考察する．なお，環状部上半分 $\left(0 \sim 180^{\circ}\right)$ 上りも下半分 $\left(180-360^{\circ}\right)$ の焼結収縮が小さいことは重力の影響が表れたこ とを示唆している.この点についても後で考察する.

Fig.6に試料基底部における収縮率の分布を示す. xはFig.3 に示したように中心からの距離を試料の横幅初期值の半分を 1として標準化したものであり，hは基底部初期位置からの上 方への変位量である. 基底部が焼結の進行とともに徐々に反 り上がっており，また昇温過程における基底各部の上方への 反りの詳細がわかる.この途中経過で基底部先端が一度垂れ

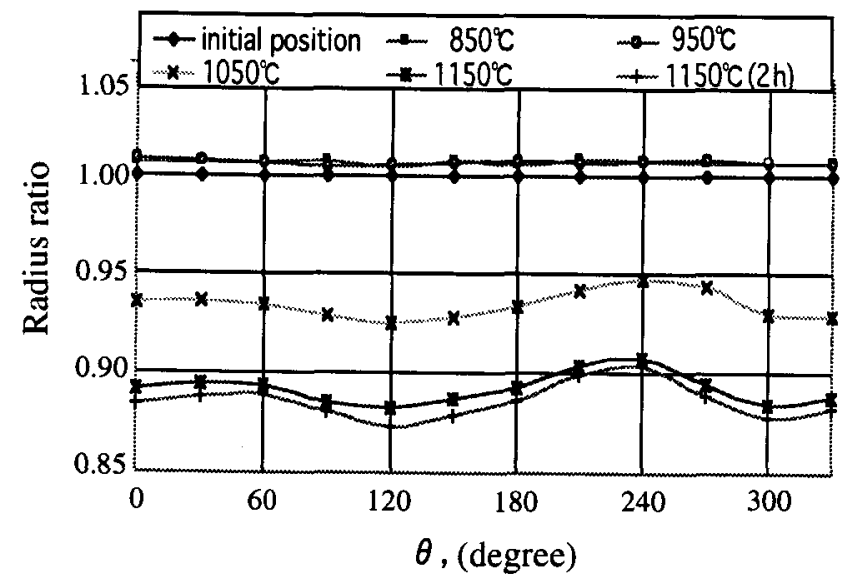

Fig.5 Radius ratio distributions of the MIM compacts along the circumference.

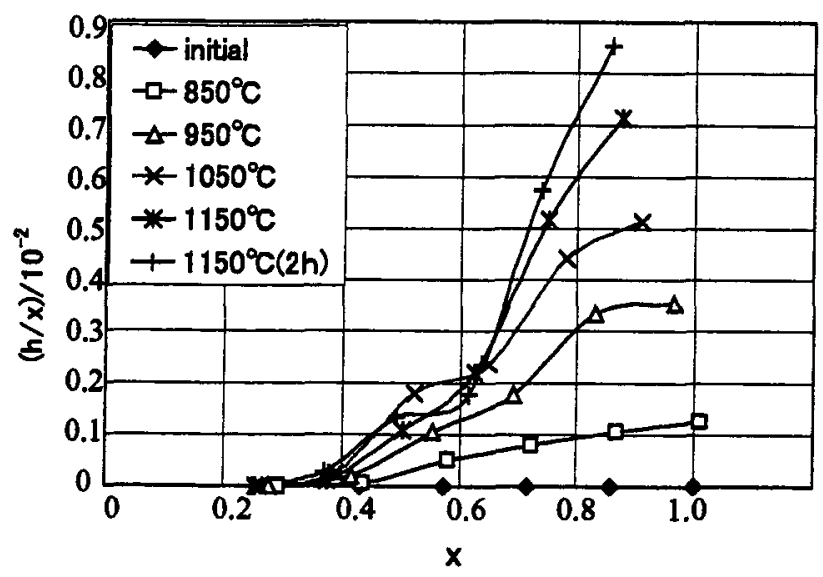

Fig.6 Upward warpage of the base plate of the MIM samples.
下がりその後元に戻っている様子なども見られ，これは重力 による収縮速度への影響が現れたことを示唆している。

Fig.7は環状部と基底部の中間部分の収縮を上下に並んだ 4ヶ所について測定した結果を表す. 昇温初期の膨張とその後 の収縮が測定各部について示されている、a,b,cはほほ同等の 収縮率を示しているが, 基底部に位置するdはほかと比べて 収縮率が小さいことがわかる。

\section{1 環状部の不均一収縮}

\section{4 考察}

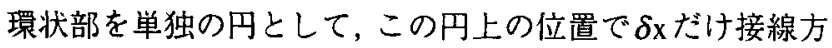
向に収縮した場合，この収縮のみによるそこから中心角で $\theta$ 離れた点における半径方向の変化量を考える(Appendix 1参照 ). $\delta \mathrm{x}$ は微小であるから当該点は $\delta \mathrm{x}$ 方向と平行に内側に向

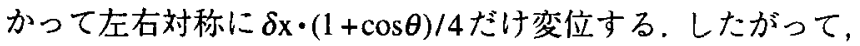
半径方向の変位は次式で表される。

$$
\delta \mathrm{r}=\delta \mathrm{x} \cdot(1+\cos \theta) \cdot \sin \theta / 4
$$

これを $\theta$ について微分すると次式を得る。

$$
\delta \mathrm{r} / \delta \theta=\delta \mathrm{x} \cdot\left(\cos ^{2} \theta+\cos \theta-\sin ^{2} \theta\right)
$$

$\delta \mathrm{r} / \delta \theta=0$ より $\theta=60^{\circ}$ となり, 半径方向の変化に最大の影響が

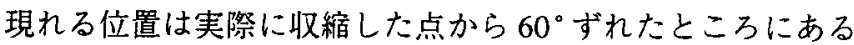
ことがわかる. Fig.4およびFig.5に示した成型体気孔率分布と 焼結過程における試料環状部半径方向の収縮率分布の位置的 なずれがこれに起因するであろうことが定性的に理解できる.

一方, 環状部は重力によって横長の棈円形に変形し，かつ 側面部分が縦方向に圧縮を受けると仮定する．環状部の円か ら棈円への変形は維方向に潰れる変形と横方向に広がる変形 とに分けて (Appendix 2 参照)，それぞれ変形率 $\mathrm{k}_{1}, \mathrm{k}_{2}$ に対して $\mathrm{k}_{1} \cdot \sin \theta$ 及び $-\mathrm{k}_{2} \cdot \cos \theta$ の変位があるとすることができるから これらによる半径方向の変位はそれぞれ $\mathrm{k}_{1} \cdot \sin ^{2} \theta$ 及びー $\mathrm{k}_{2}$ ・ $\cos ^{2} \theta$ と表される。 また，縦方向の圧縮は側面部分 $\left(\theta=0,180^{\circ}\right)$ において接線方向にのみ働くものであり，これによって環状

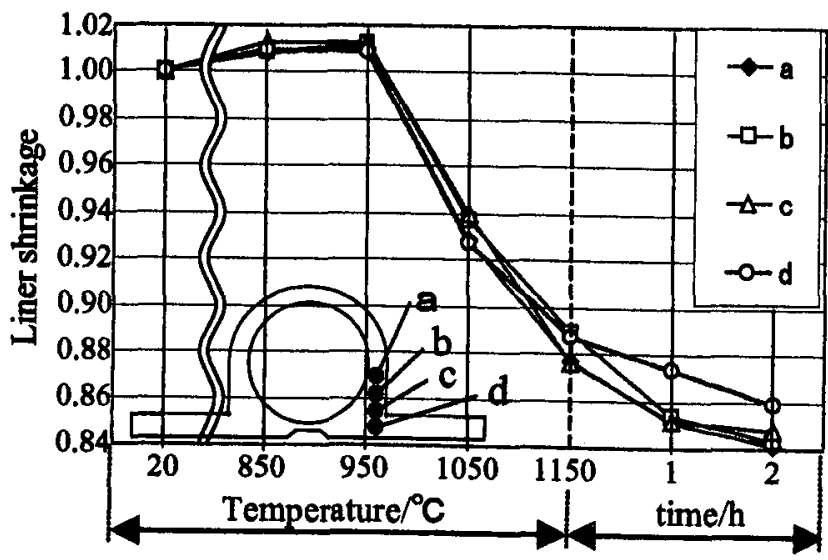

Fig.7 Non-uniform shrinkage at the side area of the compact. 
部上半分は均一に下方へ沈み込むから， $\theta=0 \sim 180^{\circ}$ について 変位係数を $\mathrm{k}_{3}$ として, 半径方向の変位は, $\mathrm{k}_{3} \cdot \sin \theta$ と与えられ る.これらはいずれも微小であるためそれぞれの加算によっ て最終的な不均一変形は次式で与えられる.

$$
\Delta \mathrm{R}(\theta)=\Delta \mathrm{S}(\theta)+\Delta \mathrm{G}(\theta)
$$

ただし，

$$
\Delta \mathrm{G}(\theta)=\mathrm{k}_{1} \cdot \sin ^{2} \theta-\mathrm{k}_{2} \cdot \cos ^{2} \theta-\mathrm{k}_{3} \cdot \sin \theta
$$

ここで, $\Delta \mathrm{R}$ は $\theta$ における半径方向の収縮量の総和, $\Delta \mathrm{S}(\theta)$ は 角度 $\theta$ における, 充填密度不均一に上る半径方向の不均一収 縮であり, 式(1)を用いた環状円の接線方向収縮による半径方 向変位の和である，密度に起因する不均一収縮がFig.4に示し た気孔率の二乗根に比例する(すなわち $\delta \mathrm{x} \propto \sqrt{\mathrm{p}}, \mathrm{p}:$ 気孔率) とし，計算による不均一変形の $\theta$ に対する分布が実測值にお ける周期的変化になるべく近くなるように，試行錯誤によっ て重力影響の係数 $\mathrm{k}_{1}, \mathrm{k}_{2}, \mathrm{k}_{3}$ を決定した. また, 計算値の平均 と最大を実測値と一致させる操作を行った。このようにして 推算したトータルの半径方向収縮比 $(\Delta \mathrm{R})$ と重力による影響を 除いた収縮比 $(\Delta S)$ を Fig.8に示した。推算曲線と実測曲線が $\theta$ について一致しないのは,この場合, 気孔率測定と収縮率測 定で製造時期の異なる試料を用いているため，ゲートからの 粉末流れの変動により，それら二つの試料間に気孔率分布の 差異が生じたことによると考えられる。計算では重力による 影響は，上方部分の沈み込みによるものが最も大きく半径に 対して $1.7 \%$ 程度であった. 側面部の広がりと側面部分の縦方 向への圧縮の影響は，それぞれ半径に対して $0.4 \%$, 及び $0.2 \%$ 程度と推算された。 なお，ここでは温度分布の不均一を無視 しているが，収絔予測が実測と良く一致する事から本試料に 扔いて温度分布の影響はほほ無かったとみなされる。

\section{2 基底部の変形}

基底部の板状部分が持ち上がった原因として，Fig.7の測定 結果から基底部すなわち一番下の点以外での収縮が大きく，

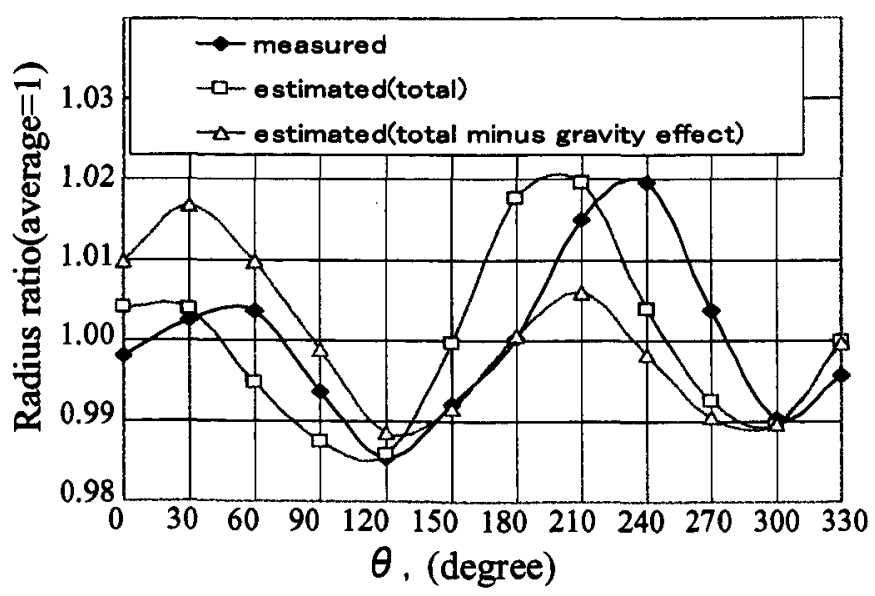

Fig.8 Measured and calculated radius shrinkage distributions along the circumference.
これによって基底部が引っ張られて反り上がったと考えられ る.またこの板の穴のあいた部分で一度下にたわんでから元 に戻るのは，この部分で断面積が小さいため焼結初期では重 力によって板の下面側に圧縮の応力が加わることで先に収縮 して緻密化し，逆に上面は粗なままであるため，その後の温 度上昇によって上面に扔ける収縮力が強まって緻密化し，ほ は真直ぐに戻うたと考えられる。また，今回は試料を立てて 測定したが通常は横に倒して焼結をするので重力の影響が無 く，基底部の反り上がりはさらに大きくなると考えられる。 これを防ぐには，充填が疎になっていた肉厚部分を削り取る ことで引っ張る力が生じないようにするか，ゲート位置を変 えることで充填状態を变える方法が考えられるが, 原因を考 えると前者の方が適当ではないかと考えられる．

Fig.9に試料全体の気孔率を示した。一般に射出成形に扔い て充填が早い部分の密度は高くなるが，それに従うように環 状部上側, 下側, ゲート付近の順に僅かずつ気孔率が上昇し ている．また，基底部と環状部との間の部分は流れの影と なって充填が不十分となっており，そのため大きな収縮が起 こったことがわかる.

\section{5 結論}

本研究で見られた不均一な焼結収縮において, 試料各部に おける左右のゲートからの粉末の流入速度差などが原因と見 られる粉末充填密度の差および重力の影響を in-situ 計測に よって確認することが出来た。これらの影響を想定したとき に予測される変化量を重权合わせて実際と比較することで, 個々の変化がどの程度の影響を持つかを明らかにした，今回 の試料に関しては, 粉末充填密度から予測される変形および 重力の影響による変形を考慮することにより，実測変化曲線 をよく説明することができた。このうち，重力による影響は 環状部の半径方向の变位で最大 $1.7 \%$ と推定された. さらに, 焼結温度保持中の充填密度差による収縮量の違い, 重力によ る応力が原因と見られる焼結速度の差なども区別することが できた。また，環状部と基底部の間において充填不十分によ る大きな収縮があり，これによる基底部の反り上がりが観察 された：そのため肉厚の中間部分を削るか，あるいは変形を 見込んで型を製作することを考えねばならないだろう。

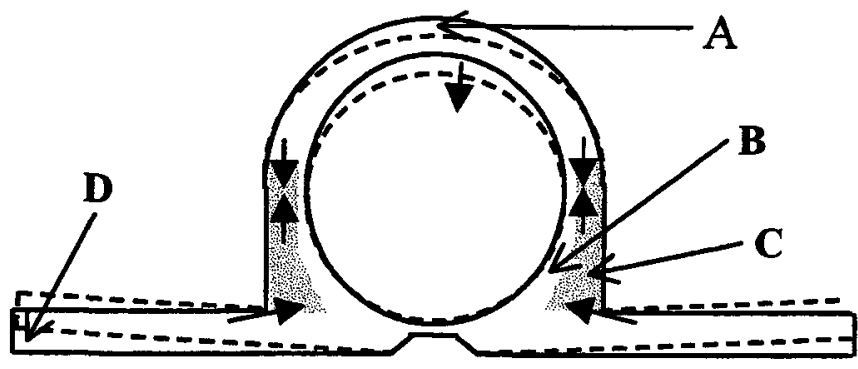

Fig.9 Non-uniform sintering shrinkage and deformation. Initial porosity (\%); A: 52.1, B: 52.2, C: 53.5 , D: 52.3. 


\section{謝 辞}

不均一変形について貴重なご意見を頂戴した住友重機工業 株式会社，徳井国人氏に謝意を表する。

\section{APPENDIX}

1. 接線方向収縮の半径方向への影響

環状部の円の接線方向と半径方向における変位の位置のず れについて，Fig.A1に示したようなXY座標の原点 $O(0,0)$ を

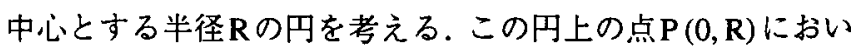

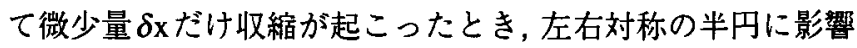
するのはそれぞれ $\delta \mathrm{x} / 2$ である。この変位により半円上の各点 はY 軸に向かって。

$$
(\delta \mathrm{x} / 2) \cdot(\mathrm{R}+\mathrm{Y}) / 2 \mathrm{R}
$$

だけ $\mathrm{x}$ 軸と平行に移動する。ここで円上の点 $\mathrm{Q}(\mathrm{X}, \mathrm{Y})$ につい て, $\angle \mathrm{POQ}$ 成す角 $\theta$ により，

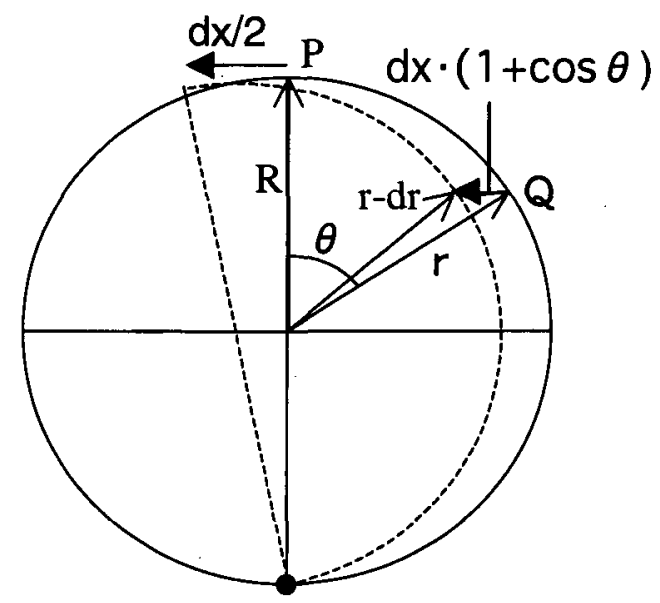

Fig.A1 The shrinkage at a point $P$ and its influence on the displacement at the different place $Q$ on the circumference.

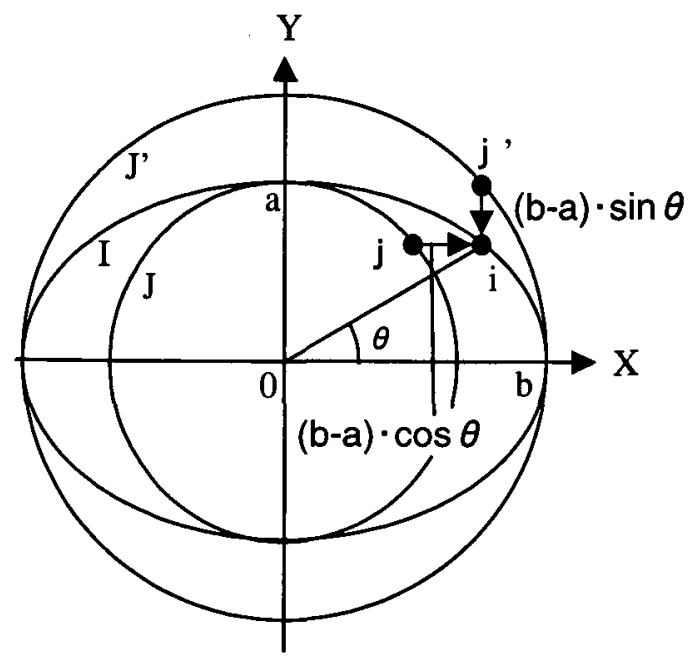

Fig.A2 Collapse and lateral extension of a circle and the accompanying vertical and lateral displacements.

$$
\mathrm{Y}=\mathrm{R} \cdot \cos \theta
$$

であるから, 式(A1)は,

$$
\delta \mathrm{x} \cdot(1+\cos \theta) / 4
$$

である，この $\mathrm{x}$ 軸と平行の変位は半径方向に対して, $(\pi-\theta)$ の角をなすから, 変形方向の変位は,

$$
\delta \mathrm{x} \cdot(1+\cos \theta) \cdot \cos (\pi-\theta) / 4
$$

すなわち，

$$
\delta \mathrm{x} \cdot(1+\cos \theta) \cdot \sin \theta / 4
$$

である。

\section{2. 重力による楕円変形}

Fig.A2に示すような X 軸方向の短辺 $\mathrm{a}, \mathrm{Y}$ 軸方向の長辺 $\mathrm{b}$

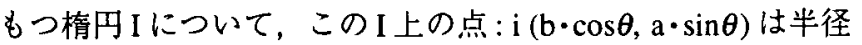
$\mathrm{a}$ の同心円 $\mathrm{J}$ 上の点 : $\mathrm{j}(\mathrm{a} \cdot \cos \theta, \mathrm{a} \cdot \sin \theta)$ に対して $\mathrm{X}$ 軸と平行に

$$
(\mathrm{b}-\mathrm{a}) \cdot \cos \theta
$$

の距離をとる。また半径 $\mathrm{b}$ をつ同心円 $\mathrm{J}^{\prime}$ 上の点: $\mathrm{j}^{\prime}(\mathrm{b} \cdot \sin \theta$, $b \cdot \cos \theta) に$ 対しては $\mathrm{Y}$ 軸と平行に

$$
(\mathrm{b}-\mathrm{a}) \cdot \sin \theta
$$

の距離にある。したがってこの 変形率として $\mathrm{k}$ とおくと, 円から横長の楕円に変形する時の 縦, 及び横方向の変位はそれぞれ中心角 $\theta$ に対して

$$
\mathrm{k} \bullet \sin \theta, \text { 及び } \mathrm{k} \bullet \cos \theta
$$

である。

\section{文献}

1) 武川淳二郎: " ステンレス鋼粉射出成型体の焼結過程にお ける変形について", 粉体および粉末治金, 40(1993)484-487.

2) 三浦立, 遠藤保夫, 坂本隆一, 斑目広和: “薄肉複雑形状 MIM 成型体の脱脂及び焼結時の变形挙動", 粉体および粉 末治金, 42(1995)97-102.

3) Y.Mizuno, A.Kawasaki and R.Watanabe: "In situ measurement of sintering shrinkage in powder compacts by digital image correlation method", Powder Metall, 38(1995)191-195.

4) 水野幸隆, 川崎亮, 渡辺龍三: “異形成形体の焼結時におけ る不均一収縮の in-situ 計測 ", 日本金属学会誌, 58(1994) 1184-1190.

5) Y.Mizuno, A.Kawasaki and R.Watanabe: "Measurement of Nonuniform Sintering Shrinkage of Functionally Gradient Material by Digital Image Processing", Metall Trans, 26B(1995) 75-79.

6）渡辺龍三, 水野幸隆: "金属粉末射出成型体の不均一焼結収 縮ーデジタル像相互相関法による in-situ 測定", 電気製鋼, 69(1998)117-130. 
7) R.Watanabe, Y.Mizuno and K.Kawasaki: "Determination of NonUniform Sintering Shrinkage in MIM Powder Compacts by Digital Image Processing", Metals and Materials, 5(1999)163-169.
8）澈澤将,渡辺龍三, 川崎亮: "デジタル像相互相間法による 射出成形体不均一焼結収濰のIn-situ測定", 粉体および粉末 治金, 48(2001)82-86. 